\title{
Typing of Enterococcus faecium by polymerase chain reaction and pulsed field gel electrophoresis
}

J. Bedendo ${ }^{1}$ and A.C.C. Pignatari ${ }^{2}$

\author{
${ }^{1}$ Departamento de Enfermagem, Centro de Ciências da Saúde, \\ Universidade Estadual de Maringá, M aringá, PR, Brasil \\ ${ }^{2}$ Departamento de D oenças Infecciosas e Parasitárias, \\ Universidade Federal de São Paulo, São Paulo, SP, Brasil
}

\section{Correspondence \\ J. Bedendo \\ Departamento de Enfermagem \\ Centro de Ciências da Saúde, UEM \\ Avenida Colombo, 5790 \\ 87020-900 M aringá, PR \\ Brasil \\ Fax: + 55-44-22-4689 \\ E-mail: Jbedendo@ maringa.com.br}

Publication supported by FAPESP.

Received August 3, 1999

Accepted June 21, 2000

\section{Abstract}

Polymerase chain reaction (PCR) with JB1 or REP consensus oligonucleotides and pulsed field gel electrophoresis (PFGE) were used to study genomic DNA extracted from 31 strains of enterococci. Eleven ATCC strains, representative of 11 species of Enterococcus, were initially tested by JB1-PCR, revealing that Enterococcus malodoratus and Enterococcus hirae presented identical banding patterns. Eight Enterococcus faecium isolates from Stanford University and 12 from São Paulo Hospital were studied by JB1-PCR, REP-PCR 1/2R and PFGE. Among the isolates from Stanford University, 5 genotypes were defined by JB1-PCR, 7 by REP-PCR 1/2R and 4 by PFGE. Among the isolates from São Paulo Hospital, 9 genotypes were identified by JB1-PCR, 6 by REP-PCR and 5 by PFGE. The three methods identified identical genotypes, but there was not complete agreement among them.

\section{Introduction}

The importance of enterococci in the etiology of hospital infections has been well documented in the literature (1-5) and knowlfor the implementation of control measures $(6,7)$.

Typing of enterococci has been accomplished by protein analysis, biochemical profiles and antibiotic susceptibility $(8,9)$. However, the lack of discriminatory power of such techniques has led researchers to develop alternative molecular-based methods $(10,11)$.

Pulsed field gel electrophoresis (PFGE) is a molecular technique in which DNA moledge of their epidemiology is fundamental

\section{Key words}

- Molecular typing

- Enterococcus faecium

- PCR-PFGE ecules are digested by restriction enzymes $(12,13)$, and the restriction fragment length polymorphism (RFLP) is used to discriminate bacterial strains $(2,14)$. Although PFGE is considered the "gold standard" for Enterococcus typing $(7,11)$, its use is limited because it is both time consuming and laborious (2).

The polymerase chain reaction (PCR) is a simpler technique that gives results within a short period of time and at lower costs. By this methodology, different primer groups, homologous, aleatory or degenerated, are used to amplify regions of the DNA molecule. Band patterns are thus produced, permitting the grouping of similar strains and the differentiation of unrelated ones (15-18). 
PCR studies undertaken to type microorganisms have demonstrated good discriminatory power when compared to PFGE $(7,17)$.

Repetitive REP $1 / 2 \mathrm{R}$ sequences are extragenic units found in different regions of the DNA of bacterial species (19). The amplification of the regions between these units produces a useful fingerprint to differentiate Enterococcus strains (20). Besides REP 1/2R sequences, other repetitive sequences have been identified in the genome of several microorganisms and have been used in typing studies (7,17,21-25). In the present study, PCR and PFGE were employed to study Enterococcus samples. Our goals were to test the applicability of the oligonucleotide primer 5'ATTTTATGGCCGTCCGC3' to amplify genomic DNA of different species of Enterococcus and to type clinical Enterococcus faecium isolates.

\section{Material and Methods}

\section{JB1 - Primer design}

The sequence of primer 5'GATTTTATG GCCGTCCGC3', called JB1 oligonucleotide primer in this study, was obtained from the intergenic space of the $16 \mathrm{~S} / 23 \mathrm{~S}$ DNA gene of sequence AF028836 (position 331 to 348 (reverse)) entered by the authors in the Gen Bank database. Sequence AF028836 (703 base pairs) was obtained from a clinical isolate of Enterococcus faecium obtained in 1997. Alignment of this sequence with those from other enterococci stored in the Gen Bank DNA database showed polymorphism in the region between base pairs 331 and 348 , where the JB1 sequence is located.

\section{Bacterial samples}

Genomic DNA from 11 species of enterococci from ATCC (E. avium 14025, E. durans 14432, E. malodoratus 43197, E. hirae 8043, E. gallinarum 49573, E. casseliflavus 25789, E. mundtii 43181, E. faecalis 19433, E. faecium 19434, E. pseudoavium 2138, and E. raffinosus 49427), 8 isolates of Enterococcus faecium from Stanford University Hospital (Stanford, CA, USA) and 12 isolates of Enterococcus faecium from the São Paulo Hospital Microorganism Bank (Department of Infectious and Parasitic Diseases, Federal University of São Paulo, São Paulo, SP, Brazil) were extracted with guanidium thiocyanate by the method of Pitcher et al. (26). DNA concentration and purity were determined with a Gen Quant spectrometer (Gen Quant, Pharmacia Biotech Inc., Uppsala, Sweden).

\section{PCR protocols}

$J B 1-P C R$. After reaction optimization, PCR with JB1 oligonucleotide primer was used to amplify 11 species of enterococci and 20 isolates of Enterococcus faecium. The reaction was carried out with $2.5 \mu \mathrm{l}$ of 10X PCR buffer (Gibco-BRL, Gaithersburg, MD, USA), $2 \mu 1$ of each of the 4 dNTPs, $1 \mu \mathrm{l}$ of magnesium chloride, 100 pmol of the oligonucleotide, 1 IU of Taq DNA polymerase (Gibco-BRL), 100 ng of genomic DNA, and twice-distilled water in up to 25 $\mu 1$. The amplification program consisted of an initial cycle of $8 \mathrm{~min}$ at $94^{\circ} \mathrm{C}$, followed by 30 cycles of $1 \mathrm{~min}$ at $94^{\circ} \mathrm{C}, 1 \mathrm{~min}$ at $55^{\circ} \mathrm{C}, 1$ $\min$ at $72^{\circ} \mathrm{C}$, and one final cycle of $3 \mathrm{~min}$ at $72^{\circ} \mathrm{C}$. Electrophoresis was carried out on $1.2 \%$ agarose gel for $3 \mathrm{~h}$ at 80 volts. The amplified fragments stained with ethidium bromide were detected by ultraviolet light.

REP-PCR. The REP consensus oligonucleotides REP1R-5'IIICGICGICATCIG GC3' and REP2-5'ICGICTTATCIGGCC TAC3' (23) were used to amplify genomic DNA of 20 Enterococcus faecium isolates. The amplification reaction was carried out with 50 pmol of opposing primers, $100 \mathrm{ng}$ of template DNA, $1.25 \mathrm{mM}$ each of $4 \mathrm{dNTPs}, 1$ IU of Taq DNA polymerase (Gibco-BRL), buffer $(200 \mathrm{mM}$ Tris $\mathrm{HCl}, \mathrm{pH} 8.4,500 \mathrm{mM}$ $\mathrm{KCl}$ ), and $50 \mathrm{mM} \mathrm{MgCl}$. The amplification 
cycle was performed as suggested by Versalovic et al. (23). PCR products were separated by electrophoresis on $1.2 \%$ agarose gel for $3 \mathrm{~h}$ at 80 volts.

\section{PFGE}

Genomic DNA was extracted from 20 isolates of Enterococcus faecium, embedded in blocks of $2 \%$ low melting agarose gel (27). DNA was digested with the SmaI enzyme (Promega Corp., Madison, WI, USA) according to manufacturer recommendations. Electrophoresis of digested fragments was carried out using a Chef Dry II apparatus (Bio-Rad Laboratories, Richmond, CA, USA) and $1 \%$ agarose gel in $0.5 \mathrm{X}$ TBEbuffer ( $45 \mathrm{mM}$ Tris, $45 \mathrm{mM}$ boric acid, and 1 mM EDTA). In electrophoresis the initial and final switch time was 5 and $20 \mathrm{~s}$, respectively, at 200 volts for $21 \mathrm{~h}$, at $4^{\circ} \mathrm{C}$. PFGE patterns were interpreted by comparing the polymorphism of the bands stained with ethidium bromide. The number of bands was determined for each sample and PFGE patterns were compared visually.

\section{Criteria used to analyze similarity among strains}

The similarity among the banding patterns produced by PCR was determined visually by comparing the molecular weight of the fragments. Banding patterns were considered to be identical if they had an identical number of fragments of the same molecular weight. In the case of PFGE, restriction patterns were considered similar or identical when they had a maximum of 2 fragments of different molecular weight.

\section{Results}

Results of PCR electrophoresis with the JB1 oligonucleotide primer used to amplify genomic DNA of 11 species of enterococci are shown in Figure 1. Identical profiles were noted in samples of E. malodoratus and E. hirae (lanes 4 and 5).

Results of JB1-PCR, REP-PCR 1/2R and PFGE of 8 Enterococcus faecium isolates from Stanford University are shown in Figure 2. Grouping of these strains by similarity is shown in Table 1. Agreement occurred among JB1-PCR, REP-PCR and PFGE for some isolates. However, identical profiles were not obtained simultaneously with the three techniques. Five genotypes were defined by JB1-PCR, 7 by REP-PCR and 4 by PFGE. Two strains run on lanes 5 and 8 were considered identical both by JB1-PCR and PFGE. However, similarity between these strains was not confirmed by REP-PCR. The strains run on lanes 6 and 7 were identical by both REP-PCR and PFGE, but different by JB1-PCR.

Results of JB1-PCR, REP-PCR and PFGE of 12 Enterococcus faecium strains from São Paulo Hospital are shown in Figure 3. Grouping of these strains (Table 1) identified 10 profiles by JB1-PCR, 6 by REP-PCR and 5 by PFGE. Similar to what occurred with $E$. faecium isolates from Stanford University, no agreement was found among the three techniques for grouping identical genotypes. Strains run on lanes 6 and 7 were considered identical when JB1-PCR was used, but grouping was not confirmed by REP-PCR or PFGE.

In this study, the banding patterns obtained by PFGE were easier to interpret than those obtained by PCR.

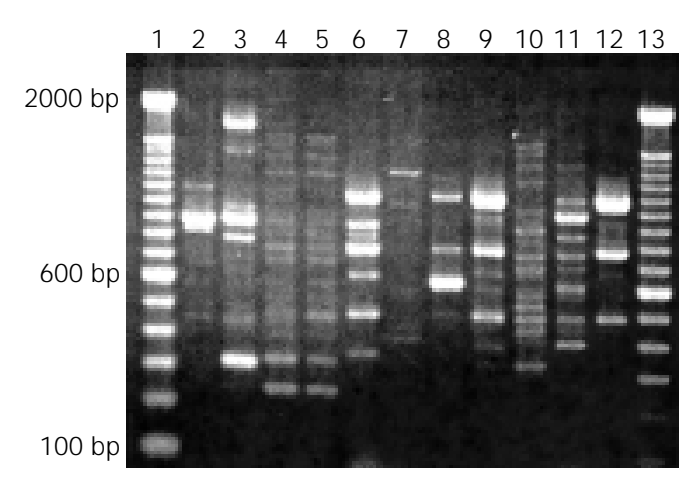

Figure 1 - PCR banding patterns of 11 enterococci ATCC strains using the JB1 oligonucleotide primer. Lanes 1 and 13, 100-bp DNA ladder; lane 2, E. avium 14025; lane 3, E. durans 14432; lane 4, E. malodoratus 43197; lane 5, E. hirae 8043; lane 6, E. gallinarum 49573; lane 7, E. casseliflavus 25789; lane 8, E. mundtii 43181; lane 9, E. faecalis 19433; lane 10, E. faecium 19434; lane 11, E. pseudoavium 2138; lane 12, E. raffinosus 49427. 
Figure 2 - PCR banding patterns and PFGE restriction patterns of 8 Enterococcus faecium isolates from Stanford University Hospital. In panels A and B, PCR banding patterns are shown with J B1 and REP-PCR, respectively. In panel C, PFGE restriction patterns digested with Smal are shown. Lanes 1 and 10 contain DNA markers. Lane 2, strain 22; lane 3, strain 8; lane 4, strain 26; lane 5 , strain 24 ; lane 6 , strain 23; lane 7, strain 6; lane 8, strain 25; lane 9, strain 21 .
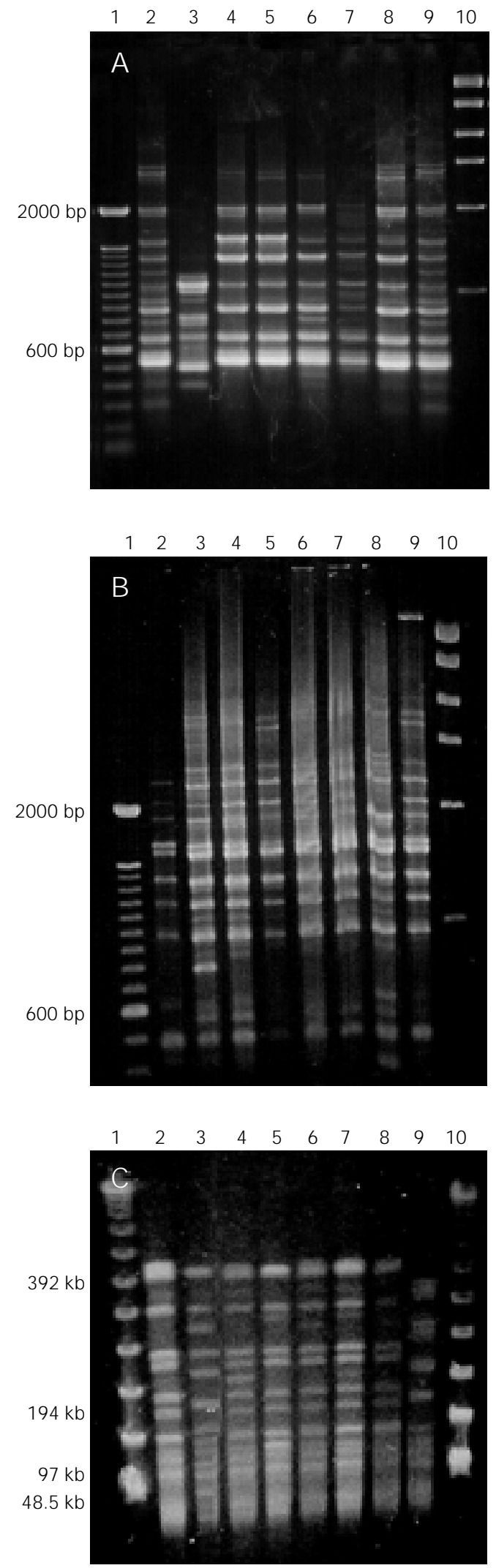

Table 1 - Identification of Enterococcus faecium genotypes obtained by J B1-PCR, REP-PCR and PFGE.

${ }^{1}$ Not classified.

Origin Strain Lane JB1-PCR REP-PCR PFGE number

\begin{tabular}{lrrrrr}
\hline \multirow{2}{*}{ Stanford } & 22 & 2 & A & A & A \\
University & 8 & 3 & B & B & B \\
& 26 & 4 & C & C & C \\
& 24 & 5 & C & D & C \\
& 23 & 6 & D & E & C \\
& 6 & 7 & E & E & C \\
& 25 & 8 & D & F & C \\
& 21 & 9 & A & G & D \\
São Paulo & 267 & 2 & A & A & A \\
Hospital & 98 & 3 & -1 & B & B \\
& 181 & 4 & B & A & B \\
& 22 & 5 & C & C & C \\
& 173 & 6 & D & C & B \\
& 21 & 7 & D & C & C \\
& 25 & 8 & E & A & D \\
& 276 & 9 & F & D & E \\
& 44 & 10 & G & E & B \\
& 107 & 11 & C & C & B \\
& 110 & 12 & H & F & E \\
& 109 & 13 & I & F & E \\
& & & & &
\end{tabular}

\section{Discussion}

In the present study, PCR with JB1 oligonucleotide amplified all ATCC strains of enterococci showing weak and strong bands. If we take into account that the amplification reaction was carried out at high annealing temperature, no random amplification occurred. The presence of strong and weak bands in the amplified products from some species may be due to a higher or lower extent of annealing between primers and target DNA.

Genetic diversity among Enterococcus faecium isolates from Stanford University Hospital and São Paulo Hospital was demonstrated by PCR and PFGE, a fact probably due to the absence of an outbreak during the collection period. A few identical genotypes were grouped by PCR and PFGE. However, strains with identical profiles were not identified simultaneously by the three techniques used. 

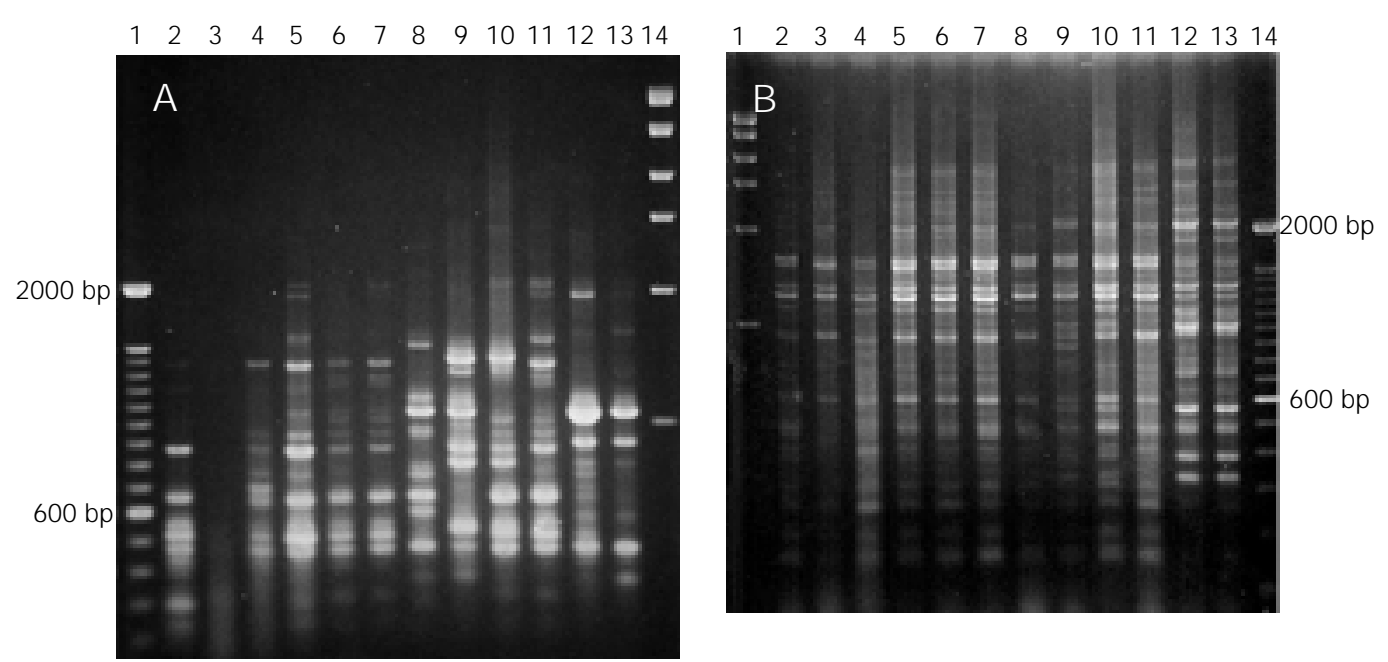

$\begin{array}{llllllllllllll}1 & 2 & 3 & 4 & 5 & 6 & 7 & 8 & 9 & 10 & 11 & 12 & 13 & 14\end{array}$

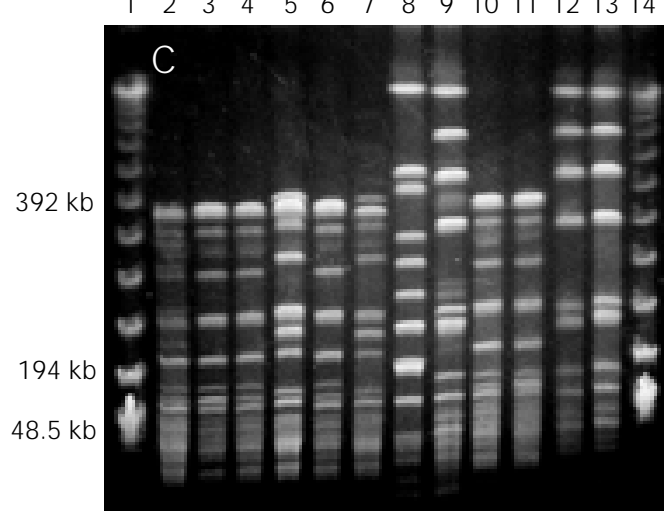

Figure 3 - PCR banding patterns and PFGE restriction patterns of 12 Enterococcus faecium isolates from São Paulo Hospital. In panels $A$ and $B, P C R$ banding patterns are shown with JB1 and REP-PCR, respectively. In panel C, PFGE restriction patterns digested with Smal are shown. Lanes 1 and 14 show DNA markers. Lane 2, strain 267; lane 3, strain 98; lane 4, strain 181; lane 5, strain 22; lane 6, strain 173; lane 7 , strain 21 ; lane 8 , strain 25 ; lane 9 , strain 276; lane 10, strain 44; lane 11, strain 107; lane 12, strain 110; lane 13, strain 109.
Malathum et al. (17) compared PCR and PFGE techniques for Enterococcus typing and did not find statistically significant differences in the discriminatory power of the two methodologies. Tenover (28) suggested a system to standardize the interpretation of PFGE patterns and to determine the relationship between strains. They suggested that 2 or more strains should be regarded as identical or closely related when a maximum of 3 bands of different molecular weights are observed. In the present study, PFGE tended to detect fewer genotypes of Enterococcus strains in comparison to PCR. This may have been consequent to the criteria used for interpretation. While by the PFGE technique 2 or more isolates could be considered identical even though they had up to 2 fragments of different molecular weight, isolates had to have exactly the same profile by PCR in order to be regarded as identical. Due to the restricted number of isolates, statistical analysis could not be applied.

Molecular techniques used to type bacterial strains differ in terms of discriminatory power, reproducibility, standardization, cost, ease of development and interpretation $(23,28)$. PFGE and REP-PCR were standardized and showed good results when employed to type Enterococcus strains. High cost and length of time make PFGE cumbersome to use in routine clinical laboratories. PCR is of lower cost and is easier to develop than PFGE. However, PCR results are more difficult to analyze, since the presence of multiple weak bands in the PCR profiles 
makes it difficult to interpret the results. PCR with JB1 oligonucleotide primer amplified genomic DNA from enterococci and showed satisfactory results when used to type Enterococcus faecium clinical isolates. Nevertheless, further studies should be undertaken to evaluate strains obtained from outbreaks.

\section{References}

1. Murray BE (1990). The life and times of the Enterococcus. Clinical Microbiology Reviews, 3: 46-65.

2. Miranda $A G$, Singh $K V \&$ Murray $B E$ (1991). DNA fingerprinting of Enterococcus faecium by pulsed-field gel electrophoresis may be a useful epidemiologic tool. J ournal of Clinical Microbiology, 29: 2752-2757.

3. Boyle J F, Soumaks AS, Rendo A, Herrington J Á, Gianarkis DG, Thuberg BE \& Painter BG (1993). Epidemiologic analysis and genotypic characterization of the nosocomial outbreak of vancomycin-resistant enterococci. J ournal of Clinical Microbiology, 31: 1280-1285.

4. Gordts B, Van Landuyt $H$, leven $M$, Vandamme P \& Gossens H (1995). Vancomycin-resistant enterococci colonizing the intestinal tracts of hospitalized patients. J ournal of Clinical Microbiology, 33: 28422846.

5. Huycke MM, Sahm DF \& Gilmore MS (1998). Multiple-drug resistant enterococci: the nature of the problem and an agenda for the future. Emerging Infectious Diseases, 4: 239-249.

6. Chow J W, Kuritza A, Shlaes DM, Green M, Sahm DF \& Zervos MJ (1993). Clonal spread of vancomycin-resistant Enterococcus faecium between patients in three hospitals in two states. J ournal of Clinical Microbiology, 31: 1609-1611.

7. Morrison $D$, J ones $B$, Egleton $C \&$ Cookson BD (1997). PCR typing of Enterococcus faecium. Advances in Experimental Medicine and Biology, 418: 387391.

8. Van Belkum A (1994). DNA fingerprinting of medically important microorganisms by use of PCR. Clinical Microbiology Reviews, 7: 174-184.

9. Thorisdottir AS, Carias LL, Marshall $\mathrm{SH}$, Green M, Zervos MJ , Giorgio C, Mermel LA, Boyce J M, Medeiros AA \& Fraimow $H$ (1994). IS6770, an enterococcal insertion-like sequence useful for determining the clonal relationship of clinical enterococcal isolates. J ournal of Infectious Diseases, 170: 1539-1548.

10. Kostman J R, Edlind TD, Lipuma J J \& Stull TI (1995). The universal approach to bac- terial molecular epidemiology by polymerase chain reaction ribotyping. J ournal of Infectious Diseases, 171: 204-208.

11. Olive MD \& Bean P (1999). Principles and applications of methods for DNA-based typing of microbial organisms. J ournal of Clinical Microbiology, 37: 1661-1669.

12. Gordillo ME, Singh KV \& Murray BE (1993). Comparison of ribotyping and pulsed field gel electrophoresis for subspecies differentiation of strains of Enterococcus faecalis. J ournal of Clinical Microbiology, 31: 1570-1574.

13. Barbier N, Saulnier P, Chachaty E, Dumontier S \& Andremont A (1996). Random amplified polymorphic DNA typing versus pulsed field gel electrophoresis for epidemiological typing of vancomycin-resistant enterococci. J ournal of Clinical Microbiology, 34: 1096-1099.

14. J ayarão BM, Dore J r JJ \& Oliver SP (1992). Restriction fragment length polymorphism analysis of $16 \mathrm{~S}$ ribosomal DNA of Streptococcus and Enterococcus species of bovine origin. J ournal of Clinical Microbiology, 30: 2235-2240.

15. Erlich AH (1992). PCR Technology: Principles and Applications for DNA Amplification. W.H. Freeman and Company, New York.

16. Dolzani L, Tonin E, Lagatolla $C \&$ MontiBragadin C (1994). Typing of Staphylococcus aureus by amplification of the 16S235 rRNA intergenic spacer sequences. FEMS Microbiological Letters, 119: 167173.

17. Malathum K, Singh KV, Weinstock GM \& Murray BE (1995). Repetitive sequencebased PCR versus pulsed-field gel electrophoresis for typing of Enterococcus faecalis at the subspecies level. J ournal of Clinical Microbiology, 36: 211-215.

18. Tyrell GJ , Bethune RN, Willey B \& Low $D E$ (1997). Species identification of enterococci via intergenic ribosomal PCR. J ournal of Clinical Microbiology, 35: 10541060.

19. Bachellier $S$, Perrin $D$, Hofnung $M \&$ Gilson E (1993). Bacterial interspersed mosaic elements (BIMEs) are present in the genome of Klebsiella. Molecular Microbiology, 7: 537-544.
20. Mercier E, J umas-BilakE, Allardet-Servent A, O'Callaghan D \& Ramuz M (1996). Polymorphism in Brucella strains detected by studying distribution of two short repetitive DNA elements. J ournal of Clinical Microbiology, 34: 1299-1302.

21. Gilson E, Bachellier S, Perrin S, Perrin D, Grimont PA, Grimont F \& Hofnung $M$ (1990). Palindromic unit highly repetitive DNA sequences exhibit species specificity within Enterobacteriaceae. Research in Microbiology, 141: 1103-1116.

22. Sharples GJ \& Lloyd RG (1990). The novel repeated DNA sequence located in the intergenic regions of bacterial chromosomes. Nucleic Acids Research, 18: 65036508.

23. Versalovich J, Koeuth $T$ \& Lupski J R (1991). Distribution of repetitive DNA sequences in eubacteria and application to fingerprinting of bacterial genomes. Nucleic Acids Research, 19: 6823-6831.

24. Heath DG, An FY, Weaver KE \& Clewell DB (1995). Phase variation of Enterococcus faecalis pAD1 conjugation functions relates to changes in iteron sequence region. J oumal of Bacteriology, 177: 54535459.

25. Van Belkum A, Scherer S, Van Alphen L \& Verbrugh H (1998). Short-sequence DNA repeats in prokaryotic genomes. Microbiology and Molecular Biology Reviews, 62: 275-293.

26. Pitcher DG, Saunders NA \& Courvalin P (1993). Rapid extraction of bacterial genomic DNA with guanidium thiocyanate. Letters in Applied Microbiology, 8: 151156.

27. Pfaller MA (1993). Molecular epidemiologic typing of nosocomial pathogens. ASCP Spring, September, Teleconference Series, lowa City, IA.

28. Tenover FC, Arbeit RD, Goering RV, Mickelsen PA, Murray BE, Persing DH \& Swaminathan B (1995). Interpreting chromosomal DNA restriction patterns produced by pulsed-field gel electrophoresis: criteria for bacterial strain typing. J ournal of Clinical Microbiology, 33: 22332239. 